\title{
The Countryside of Roman Britain: A Gallic Perspective
}

\author{
By MICHAEL FULFORD
}

\begin{abstract}
The publication of the RurLand (Rural Landscape in North-East Gaul) project has provided an opportunity to compare methodologies and results with those of The Rural Settlement of Roman Britain project. Two themes, which draw out the asymmetrical development of settlement in the two regions, are examined: the very different impacts of the Roman conquests of Gaul and of Britain on settlement numbers and settlement continuity, and the development of the agricultural economy and its relationship with the frontiers of Britain and Germany, as reflected in the growth and decline of villa estates in Britain and Gaul.
\end{abstract}

Keywords: agricultural economy; Boudican; conquest; corn-drying oven; Cotswolds; frontiers; Gallia Belgica; granaries; human osteology; Iceni; invasion; migration; mills; Natural Areas; peasantry; Picardy; population; RurLand; The Rural Settlement of Roman Britain project

$\mathrm{T}$

he publication in two volumes totaling more than 1,500 pages of the results of Michel Reddé's European Research Council-funded RurLand (Rural Landscape in North-East Gaul) project ${ }^{1}$ prompts reflection on the outcomes of The Rural Settlement of Roman Britain project (RSRB) whose principal outputs were published as The Rural Settlement of Roman Britain: An Online Resource (2015, updated 2018) ${ }^{2}$ and the three-part New Visions of the Countryside of Roman Britain. ${ }^{3}$ The two projects had different aims and methodologies, and, while it would have been exciting if these had been the same, thus facilitating the simultaneous research of similar problems in both Britain and Gaul, RSRB had already begun in 2012, its methodology, drawing on earlier pilot projects, ${ }^{4}$ set out in the grant applications of the previous year to The Leverhulme Trust, and unaware that a similar project was in prospect across the Channel. RurLand commenced in 2014. The major contribution that the publication of RurLand has made to our knowledge and understanding of the settlement and agricultural economy of north-eastern Gaul invites us to reflect back on several themes that arise from the analysis of our British data.

\footnotetext{
$1 \quad$ Reddé 2017; 2018.

2 https://archaeologydataservice.ac.uk/archives/view/romangl/ (accessed February 2020).

3 Allen et al. 2017; Smith et al. 2016; 2018.

$4 \quad$ Fulford and Holbrook 2011.
} 


\section{METHODOLOGY AND APPROACHES}

Although RSRB had originally been envisaged as a vehicle for demonstrating the knowledge gained by developer-funded interventions since the implementation of Planning Policy Guidance 16 in 1990, particularly focusing on the difficult-to-access records which existed only as 'grey literature' reports archived in local authority Historic Environment Records (HERs), it took the view that such selectivity would not be beneficial if the overarching aim was to address a range of social and economic questions concerning the settlement and people of the countryside of Roman Britain. It was decided that all available and relevant sources, published and unpublished, should be utilised in order to give as complete an account as possible. Funding from the public body, English Heritage (Historic England since 2015), enabled access to the 'grey literature' from all HERs across England. RurLand, on the other hand, focused on the areas where there had been significant contributions to knowledge from developer-funded archaeology in north-eastern Gaul, an area which corresponds with a large area of Gallia Belgica, but also included parts of other neighbouring provinces. To research Roman Britain, or the Britain south of Hadrian's Wall that was under continuous Roman control from the late first to the beginning of the fifth century, required access to the results of investigations of only two nations, with the outputs which needed to be accessed all in English. By contrast, to achieve complete coverage of Gallia Belgica would have involved accessing the resources from five nations and publications in, mostly, four languages.

RSRB chose to be selective in its choice of sources, including in the project only those sites with good plan evidence and/or with finds' assemblages susceptible to a quantitative approach and having the potential to address a range of economic and social questions about the countryside and the rural population. Our sample was drawn from both published and unpublished 'grey literature' reports. Selected sites therefore comprised those with good plan evidence, quantified assemblages of material culture, animal and plant remains and funerary evidence, including reports on the skeletal remains, hopefully, but by no means exclusively, in combination. ${ }^{5}$ Altogether the total number of individual sites included in the study is some 2,500 , with considerable variation in numbers between regions, reflecting where development since 1990 has been the most intense. Since the great majority of sites were not protected as Scheduled Ancient Monuments, and since the great majority of the latter in the countryside are villas or temples, very few of these two categories of site have been excavated and published since 1990. On the other hand, settlements classified as open, enclosed and complex farms, but rarely associated with masonry structures, are well represented, giving a new perspective on the countryside of Roman Britain. Numerically the Central Belt and the South regions account for about 80 per cent of the sites with, respectively, some 1,090 and 897 sites, while, by contrast, the North, the South West and the Upland Wales and the Marches regions account for only, respectively, 123, 115 and 120 sites that met the selection criteria. This variability immediately raises questions of the representativeness of the datasets and the robustness of our conclusions, particularly outside the Central Belt and the South regions.

\section{THE IMPACT OF CONQUEST}

One important question we asked of RSRB was what evidence could be discerned of the impact of the early years of the Roman conquest of Britain, launched in A.D. 43. Across the Channel there appears to be very strong evidence that the Caesarian conquest of northern Gaul was of a very predatory nature, with no indication of a plan for permanent occupation; it deprived the

5 Fulford and Brindle 2016, 8-15. 
landscape of people and portable wealth causing major disruption with widespread evidence of settlement abandonment. ${ }^{6}$ Certainly settlement numbers show a precipitate decline from their peak at c. 100 B.C. $^{7}$ With southern Britain, the opposite seems to be the case, with evidence of significant growth in the numbers of new settlements both in the Late Iron Age and the first century A.D. ${ }^{8}$ The two trends either side of the Channel are almost certainly connected. While it became unfashionable in the late 20th century to regard changes in material culture and burial rite in the Late Iron Age of south-eastern Britain as evidence of migration from the near continent, the combination of different types of evidence, including the potential of aDNA analysis, suggests this view needs to be revisited. An emerging strand is the lack of continuity of settlement from the Early or Middle Iron Age of the south-east of Britain into the Late Iron Age compared with the emergence of de novo Late Iron Age foundations. The latter are associated with a distinctive material culture, of which the so-called Belgic-style, wheel-thrown domestic pottery is the most abundant category, and the similarly distinctive and spatially co-related burial rite of cremation. ${ }^{9}$ While we need radiocarbon dating to help us refine the chronologies of Late Iron Age settlement in the south-east of England, there does seem to be a post-Caesarian acceleration.

For Britain, the immediate post-conquest period is further complicated by the Boudican rebellion, which, if the destruction and loss of life as indicated by the written sources is anywhere near accurate, one might expect to be visible in the settlement record. However, since there are barely 20 years between the invasion of A.D. 43 and the Boudican rebellion of A.D. $60 / 61$, it is as yet not possible to see distinctions in the material culture record that would allow one to determine whether a settlement's abandonment could be attributed to one or other event. Radiocarbon dating offers the possibility of a way forward, but a considerable number of dates would be required to refine chronologies to within a 20 -year time span, but rural settlements lack the stratigraphic complexity that would facilitate statistical modelling of the dates. Nevertheless, if we are to make progress in understanding the Late Iron Age and first century A.D., even in comparatively material-rich southern Britain with quite narrowly dated typologies, establishing radiocarbon-dated chronologies has to become the norm.

In light of the evidence from Gaul, ${ }^{10}$ the aftermath of conquest and the suppression of rebellion together would surely have led to a loss of settlements in southern Britain? However, if we consider the East region, which includes the territory of the Iceni, and where data from 182 sites were examined, settlement numbers show a significant rise in the Late Iron Age, with 85 per cent new foundations, and the first century A.D., with 60 per cent new foundations, and correspondingly small proportions of abandonments. ${ }^{11}$ The figures are a little, but perhaps surprisingly, different from the Central Belt and the South, where the proportions are less, at approximately 65 and 35 percent new foundations. ${ }^{12}$ Introducing a note of caution, if we look at the data more closely, we find that the recorded settlements concentrate more in the south of the East region, not in the north and in certain Icenian territory. ${ }^{13}$ Perhaps it is premature to draw conclusions about the effect of conquest and rebellion on the part of the Iceni? Yet, if we extend the timescale into and through the Roman period, we can potentially detect an impact in the way the territory stands out from its neighbours to the west and south in its lack of villas

cf. Roymans 2019; Roymans and Fernández-Götz 2019, 450-55.

Malrain and Lorho 2018, fig. 14.

e.g. Allen 2016, 81, fig. 4.6; Smith 2016b 148, fig. 5.8 .

Allen 2016, 83, fig. 4.8; Smith 2016b, 149, fig. 5.8; 2018, 220-2, fig. 6.12.

Roymans 2019; Roymans and Fernández-Götz 2019, 450-5.

Smith 2016c, 214-15, fig. 6.8 .

Allen 2016, 83, fig. 4.8; Smith 2016b, 149-51, fig. 5.8.

Smith 2016c, 209-12, fig. 6.5. 
and a corresponding dearth of town houses in its small civitas capital, Venta Icenorum, ${ }^{14}$ implying both a lack of privately owned estates on the part of the Icenian aristocracy and insufficient resources to fund an urban lifestyle. Did the Icenian territory become an imperial estate, its people enslaved, after the revolt and remain thus through succeeding generations? ${ }^{15}$ On the other hand, the place name, Venta Icenorum, suggests the tribal territory eventually had a similar status as elsewhere in the province, though we do not know who actually ran the civitas.

However we interpret the settlement pattern of the Iceni, we are still left with trying to explain the huge difference between the Gallic (Belgic) and the British experience of conquest. Was there a deliberate policy not to cause too much destruction in Britain, including discouraging the removal of manpower as slaves, at least from the potentially agriculturally productive south, in order to mitigate any concerns that the Roman army could be isolated from supplies from across the Channel and depend wholly on provision from within Britain? Such a concern is still evident when the legionary fortresses at Caerleon, Chester and York were founded in the late first century A.D. These, which were to become the 'permanent' legionary garrisons of the province, were all located next to navigable rivers, not too distant from the sea. Yet, as we have seen, settlement numbers in the south actually continued to increase through the first century A.D., probably more through continued inward migration, and now as a result of merchants, such as those settling in London, and legionaries and auxiliaries choosing to stay in the province on their retirement, rather than through indigenous population growth.

Similarly, while recovery of the indigenous population may correspond with the continuation of Late Iron Age farms into the first century A.D., inward migration to northern Gaul from the Augustan period onwards may better account for the steepness of the rise in settlement numbers, including the development of villas, than indigenous population growth. ${ }^{16}$ Looking back to the first century B.C., in the same way that we have proposed a greater use of radiocarbon dating to understand the development of settlement in Late Iron Age and first century A.D. Britain, a similar application would surely be helpful in gaining greater clarity on the timing of the decline in settlement numbers in Gaul in the first century B.C. and the extent of its synchronicity in relation to the Gallic wars as well as on the rate of rise through the first century A.D. in northern Gaul.

Although both the British and Gallic evidence show an increase in numbers of settlements from the second half of the first and through the second century A.D., the character of rural settlement differs markedly between southern Britain and northern Gaul, which sees the rise of the grande villa, particularly the types with axial plan. ${ }^{17}$ With remarkable exceptions, such as the Flavian 'palace' of Fishbourne, developments such as these do not occur in the south of Britain, the Central Belt and South regions, before the late third and fourth centuries. It is not clear why this should be so. The late Empire is also the time when, looking at the broad trends in numbers, a further potential correlation can be seen between the patterns of settlement in Britain and northern Gaul in the later Roman period. This is one of decline in numbers over much of northern Gaul, which is matched by a comparable decrease, but only among the coastal counties of eastern and south-eastern England. ${ }^{18}$ On the other hand, in the western counties of southern Britain, there is continued growth in the number of settlements, including

Bowden 2013, esp. fig. 3.2.

c.f. Frere 2000.

RurLand case studies: e.g., for the Nervian territory, see Clotuche et al. 2017, 182, 191, figs 4-6, 15; for the lower Seine, see Spiesser et al. 2017, 220-1, figs 13, 15; for the Amiens region, see Bernigaud et al. 2017b, 285, fig. 26; for the valley of the Oise, see Malrain et al. 2017, 319, fig. 9; for the île de France, see Bernigaud et al. 2017a, 478, fig. 64; for the territory of the Remi, see Achard-Corompt et al. 2017, 518, fig. 18.

17 Nüsslein et al. 2018.

18 See n. 16 for northern Gaul; for Britain, East region, see Smith 2016c, 215, fig. 6.8; for South East, see Allen 2016, 83-4, figs 4.8-9. 
the rise of villas and 'palatial' villas like Chedworth and Woodchester, in the Cotswolds landscape zone up to the mid-fourth century. ${ }^{19}$ Elsewhere in the South and Central Belt regions settlement numbers had peaked by c. A.D. 200, some 150 years earlier. It is difficult to explain this anomaly, but, when seen now in the context of settlement patterns across southern Britain as a whole, the argument, first advanced by Leo Rivet on the basis of similarities in villa plans in Britain and Gaul, that the growth in the numbers of villas in the West Country represented a flight of estate owners from northern Gaul in the wake of the disruptive barbarian invasions across the Rhine in the mid-third century remains attractive. ${ }^{20}$ The counterargument that some of these developments took place on sites with earlier occupation and were therefore the result of indigenous initiatives remains a possibility, but continuity of settlement does not necessarily equate with continuity of ownership, nor readily explain the sources of capital that enabled such step changes as the building and furnishing of a villa.

\section{THE RURAL ECONOMY AND THE QUESTION OF CONTROL}

The RurLand project concentrated on two major themes: the settlements (and their constituent architecture) and the agricultural economy as mediated through the botanical and zoological record. RSRB, on the other hand, looked to employ the evidence of material culture as well as that of plant and animal remains to address a greater number of questions. Both projects look back to the Iron Age in order to put the Roman period in context and to explore the extent of settlement continuity, including the persistence of 'farms' alongside the development of 'villas'. However, while RurLand successfully demonstrates the considerable variety of farm and villa types in its various selected study areas, and synthesised for the study area as a whole, ${ }^{21} \mathrm{RSRB}$ proposes a framework for Roman Britain of eight regions, developing earlier approaches that have moved us forward from the binary 'upland/lowland', 'villa/non-villa' divisions which have previously framed synthesis. ${ }^{22}$ In defining the limits of those regions and to avoid the constraints of modern political geography, it took account of Natural England's 'Natural Areas', which introduced further refinement within each region. ${ }^{23}$ Where sufficient data allowed, certain 'Natural Areas' provided the basis for more nuanced case studies in each of the eight regions. For example, the Central Belt provided an assessment of the settlement of the Cambridgeshire Fen Edge, drawing on the data from two 'Natural Areas', the Fens and the West Anglian Plain. ${ }^{24}$ The data from the latter were sufficiently rich also to provide case studies in Lisa Lodwick's review of arable farming ${ }^{25}$, Martyn Allen's of pastoral farming ${ }^{26}$ and in those authors' analysis of agricultural strategy. ${ }^{27}$ These case studies are, of course, an admission that the eight regions are relatively crude constructs, perhaps best illustrated by the South-West region where West Cornwall, embracing the Natural Areas of the Cornish Killas and Granites, The Lizard and West Penwith, has a distinctiveness in numerous aspects: settlement morphology, buildings, material culture, plant and animal remains. ${ }^{28}$ With its in-depth approach to its selected study areas, in the first volume of Gallia Rustica (Reddé

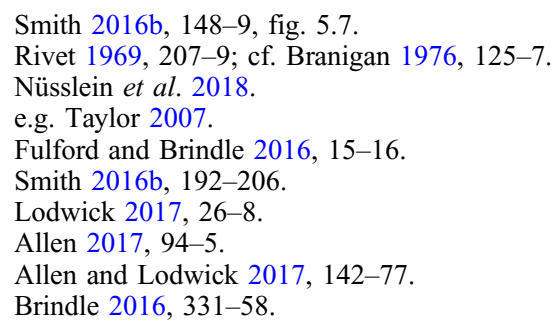


2017) RurLand avoided the need to make compromises of this kind while at the same time demonstrating the rich variability in settlement types, settlement histories and agricultural economies, while taking account of the different geologies and soils. There remains, therefore, the opportunity to look for the similarities and differences which might allow for the definition in northern Gaul of regions akin to the British model and for the relationships with the equivalents of England's Natural Areas. Nevertheless Sébastien Lepetz and Véronique Matterne have shown some regionality in their systèmes agro-pastoraux when they contrast the cattle and spelt/caprines and barley combinations found in Britain, especially in the Central Belt and South regions, with the situation in north-eastern Gaul. In the north, in Gallia Belgica, the combination of hulled wheats, oats and flax was favoured, while in the Paris Basin it was free-threshing wheats, lentils and bitter vetch, and in the east, barley, spelt wheat and millets. ${ }^{29}$ Equally, for Britain there remains the opportunity to research the relationship of settlement with soils and geologies, taking account of the entirety of the settlement evidence recorded in HERs, rather than adopting the selective approach of RSRB. ${ }^{30}$

What has been critical for the RSRB project has been the ability to make comparisons on the basis of quantified data - numbers are crucial! This is true of all categories of information, from the settlements themselves through the associated material culture and plant and animal remains. With the available data, it has been possible to demonstrate that across the regions different types of settlements have distinct identities, for example, that enclosed farmsteads in the Central Belt were materially poor compared with complex farmsteads or villas in terms of both varieties and quantities of artefacts. Villas, on the other hand, are much more likely to have dress accessories, writing and lighting equipment, military fittings and weaponry, and locks and keys. ${ }^{31}$ With roadside settlements, those that were provided with defences have a very different material identity to those that were not. ${ }^{32}$ But, as Neil Holbrook and I have argued, we need to do more than this and encourage the profession to develop a volumetric approach in reporting excavations in order to gauge intensity of consumption at different types of site and in different regions. This requires the assessment of finds assemblages in relation to the volume of soil excavated. ${ }^{33}$ Publication of datasets in formats much more amenable to reuse, such as csv data tables, would also be very helpful.

One of the several important developments in archaeology in recent decades has been the development of human osteology, such that sufficient data of quality enabled Anna Rohnbogner to offer an analysis of the living conditions of the population of late Roman Britain, the sample very largely drawn from the Central Belt and the South regions. ${ }^{34}$ The combination of several strands of evidence, including morbidity rate, disease, nutritional deficiency and skeletal trauma deriving from hard physical work, paints a grim picture of life in the countryside, a far cry from notions of a 'golden age' equated with fourth-century villa development and élite display. ${ }^{35}$ Strikingly, though the Iron Age dataset is small, Rohnbogner reports 'A considerable decline in health, measured in a significant increase in the frequency and variety of pathological lesions between the Iron Age and rural Roman Britain.' ${ }^{36}$ While we do not have comparable datasets from northern Gaul, there are other aspects of the rural

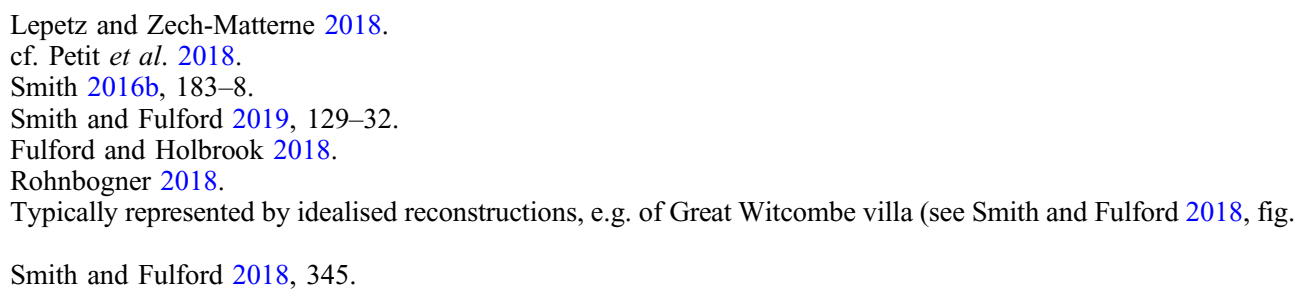




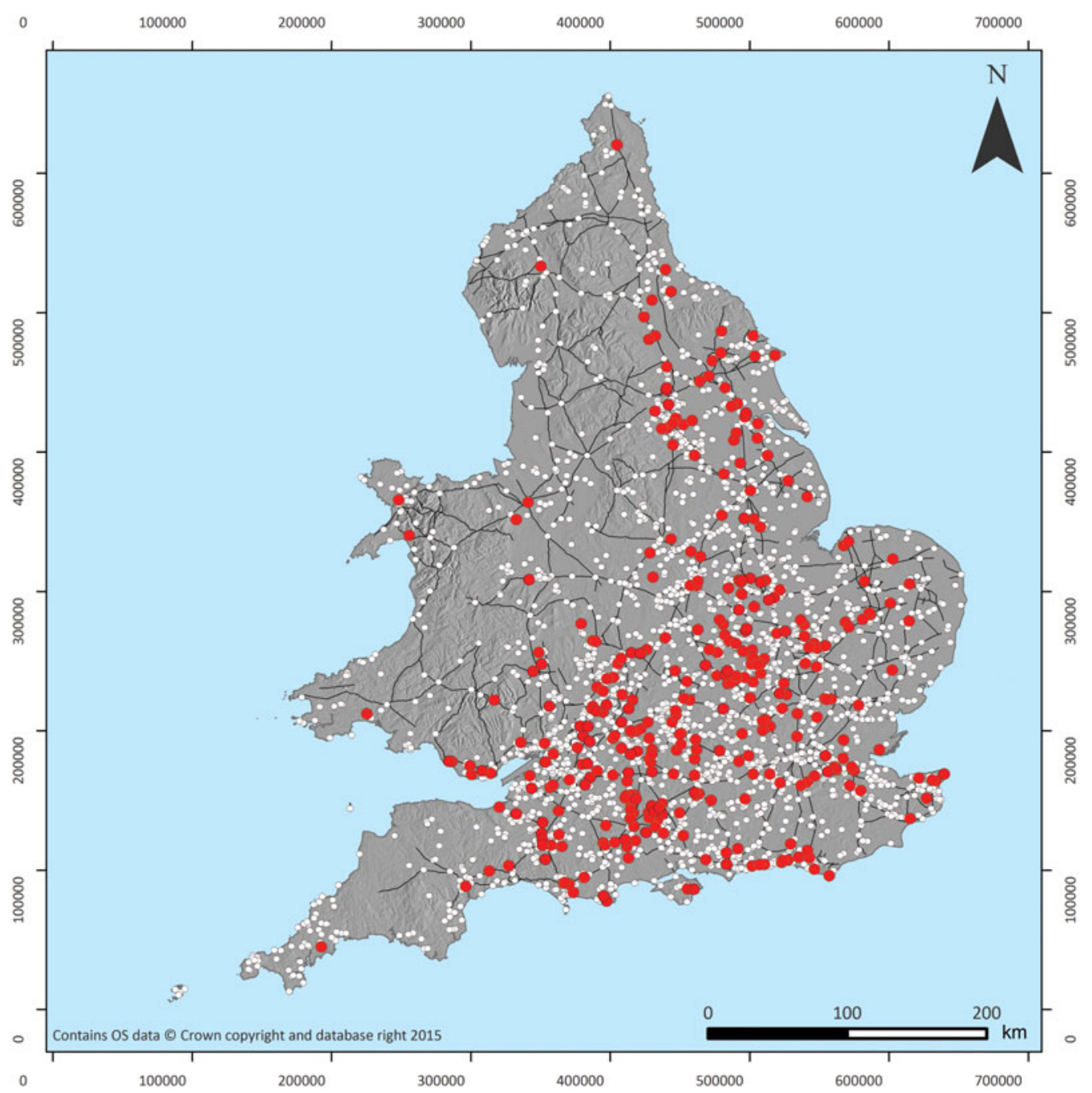

FIG. 1. The distribution of excavated sites with corn-dryers (red) in Britain and other settlements (white) (after Smith et al. 2016, fig. 3.11).

economy where a comparison with the British evidence may be helpful in giving further context to the osteology.

A notable and ubiquitous feature of the British countryside from the second century onwards is the corn-drying oven (FIG. 1). ${ }^{37}$ Given that the surface area of these structures is typically less than about $5 \mathrm{~m}^{2}$, only relatively small quantities of grain could be dried at any one time. Thus the harvest from one field alone might have required several firings of the oven. ${ }^{38}$ Yet, when we consider that fuel had to be gathered for each operation, perhaps as little as $50 \mathrm{~kg}$ of grain to be

37 Lodwick 2017, 55-61. In some cases the evidence suggests interpretation as malting ovens (Lodwick 2017, 626).

38 Experiments suggest that it could have taken as long as two months to dry a 10 tonne harvest (Reynolds and Langley 1979). 
dried at a time, the process was still perceived to be worthwhile. One explanation for their increased incidence from the mid-Roman period onwards is a wetter climate which required greater reliance on assisted drying of the crop. Another explanation may be increased insecurity encouraging harvesting in suboptimal conditions. Overriding these explanations is the implication of the value attached to saving as much of the harvest as possible. While granaries are puzzlingly rare in the countryside of Roman Britain, particularly in the early Empire, but even in the late third and fourth centuries, where they are found, their association is consistently with villas. ${ }^{39}$ This contrasts with north-eastern Gaul where granaries are a regular feature of the rural landscape in the early Empire, allowing landowners control over when they sold their harvests, but less so in the period of rural decline in the third and fourth centuries. ${ }^{40}$ Perhaps it was the villa owner who, through his demands on his tenants for harvest returns, was the main driver behind the development of corn-dryers which were used to ensure that quotas were met while allowing for the possibility of retaining some surplus for seed corn and domestic consumption. Dryers are also present, but not in such numbers, in north-eastern Gaul. ${ }^{41}$ This, too, may be a function of decreasing settlement numbers, but otherwise both environmental conditions and overall security could not have been very different from the situation prevailing in Britain. The behaviour exemplified by the emergence of the dryer in Britain and Gaul may, perhaps, be best explained by a more exacting regime of control over the peasantry, at the moment more evident in Britain than in Gaul, where landowners exercised strict control over harvests. ${ }^{42}$

Such a notion of control may also be seen in the incidence of millstones compared with domestic querns in later Roman Britain. ${ }^{43}$ The development of dedicated mills in the countryside also supports the idea of greater control over harvests and consequently over the production of flour for tenants and the peasantry. A reasonable speculation in this context is that landlords took the entirety of the harvest, leaving the peasantry with control over neither seed corn nor what they needed for domestic consumption. This picture of a strictly controlled peasantry in the late Roman countryside of Britain chimes not only with the osteological evidence, but also, as another indicator of its poverty, with the lack of diversity of material culture in the rural landscape of late Roman Britain beyond the villa. Finds' assemblages are overwhelmingly dominated by pottery, with dress and personal accessories very much in the minority; brooches, for example, relatively common in the first and second centuries, are a rarity in the countryside beyond the villa in the later third and fourth centuries. Surprisingly perhaps, the commonest find, second only to pottery sherds, is the copper-alloy nummus. ${ }^{44}$ This poverty is perhaps reflected in the burial evidence, where only 20 per cent of late Roman graves in the south are found to be furnished compared with about 50 per cent in the early Roman period. While explanation for this shift in behaviour may reflect a cultural shift rather than economic hardship, the pottery vessel is the most popular category of grave good, more than twice as common as hobnails/shoes or animal remains. ${ }^{45}$ With little else evident in the archaeological record which a collection of nummi might buy, we might assume that coins targeted the acquisition of perishables like food (including, perhaps, buying flour from the landlord's mill) and clothing. Even here there seems to be a change of practice from the Late Iron Age and early Roman period in that artefacts associated with textile manufacture, typically the spindle-whorl, are rare in the later Roman period - evidence perhaps of the landowner or

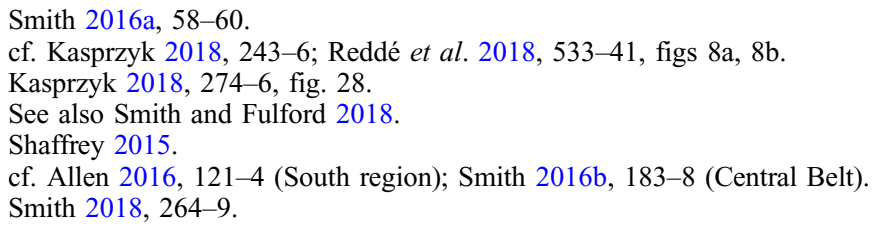


other authority taking close control not only of the cereals produced on his land, but also of wool and textile production. ${ }^{46}$

In considering the destination of agricultural surplus in Roman Britain, studies of town-country relationships as reflected in the evidence of pottery as a proxy for perishable and other goods have questioned the extent to which the major towns functioned as markets. ${ }^{47}$ While there is clear evidence in the form of the rows of narrow-fronted tabernae that through traffic generated business along the main roads, it is far less obvious that markets operated, drawing in people from the countryside. Indeed, it is a striking feature of the major towns of Roman Britain how little satellite settlement developed around them, London being particularly notable in this regard. Examples where clustering is evidenced are nucleated settlements of uncertain status, perhaps best regarded as vici, such as Bath, Ilchester and Water Newton, comparable with some of the agglomérations of northern Gaul. ${ }^{48}$ In contrast to the major towns of Britannia, developer-funded research in northern Gaul reported by the RurLand project shows dense halos of settlement around the Roman predecessors of cities like Amiens, Paris, Reims and, above all, Trier. ${ }^{49}$ But such relationships are not always the case: the clustering of villas towards the centre of Gaul in the Côte d'Or and Burgundy does not relate to any particular civitas capital; rather, it is the villas' proximity to the road network and roadside agglomérations that commands attention. ${ }^{50}$ This is reminiscent of the situation in Britain. But also, just as in Britain, there are the negatives to puzzle over: the areas of northern Gaul generally lacking in villa development, ${ }^{51}$ more specifically, the conspicuous lack of villa development in the hinterland of the colonia at Xanten compared with the dense distribution in the territory of eponymous Cologne, ${ }^{52}$ only some $100 \mathrm{~km}$ distant up the Rhine. These examples remind us of the lack of villa development in fertile regions of Britain such as the West Midlands, the Cheshire Plain and the Vale of York, including around the fortress and colonia of York itself, a situation which 25 years of developer-funded archaeology has not significantly changed. ${ }^{53}$

Reddé rightly draws attention to the impact of the German frontier on the development of the Gallic countryside, ${ }^{54}$ but the conquest and occupation of Britain also surely had a major impact on Gaul, giving it the opportunity to service two frontier systems. Its most visible mark in Britain can be seen in the ubiquity of Gallic sigillatas between the mid-first and mid-third century A.D., but we still have little idea of how either the initial expansion of production to supply consumers in both Britain and Germany or the cessation of production affected the hinterlands of the major producers, such as at La Graufesenque or Lezoux, or of the networks that delivered the products to the consumers. The rise and fall of other, much less archaeologically visible, but strategically more important goods, of which cereals and other foodstuffs were probably the most important, would also have had their impact. The increase in density of settlement around Amiens and in Picardy through the later first and second centuries is noted above, ${ }^{55}$ and, given the city's situation on the Somme with access to the Channel and the southern coast of Britain, we may speculate whether this was related to the satisfying of demand for goods, both material and, probably in particular, foodstuffs, in Britain. By the same token, the rise of villa estates in

Brindle and Lodwick 2017.

Fulford 2017, 359-61.

48 Kasprzyk and Monteil 2017

49 Nüsslein et al. 2018, 182-91, figs 36, 38-41; also Bernigaud et al. 2017b (for the region around Amiens); Bernigaud et al. 2017a (for the region around Paris); Achard-Corompt et al. 2017 (for the region around Reims).

50 Nüsslein 2018, figs 52-5.

51 Nüsslein et al. 2018, n. 49

52 Brüggler et al. 2017.

53 Smith et al. 2016; cf. Sargent 2002, 224-6.

54 Reddé 2018

55 n. 49 
Britain from the later third century onwards may, in part at least, have been a response to the decrease in settlement around Amiens and in Picardy from the mid-third century onwards. Where previously contracts for grain to supply the needs of the British and German frontiers had been placed with Gallic farmers, now, to meet the needs of Britain at least, these were to be placed exclusively within the province itself. However, as is well known, by the mid-fourth century, if not before, British cereals were also supplying the Rhine frontier. Looking to the potential direction of future research of cross-Channel relations during the third and fourth centuries, critical questions that await resolution are whether the cessation of, inter alia, the flow of Lezoux sigillata, Baetican oil-carrying amphorae and wine amphorae from Narbonnensis into Britain in the early third century was coincidental or the result of separate, local failures, whether it connected in any way with the decrease in settlement in northern Gaul or whether it was the result of a larger, overarching policy decision to look to local solutions to issues of supply, in this case to Britain itself.

\section{CONCLUSION}

The RurLand project has given us the basis for comparing and contrasting the settlement morphologies, trajectories and agricultural economies of Britain and north-eastern Gaul, and we look forward to future research which explores the material culture, the religious and funerary behaviour in the countryside, and the character of the rural population itself through its skeletal remains. The potential for future research and reassessment would be greatly enhanced if the underpinning data of RurLand were available online in the same or similar way that the underpinning data RSRB are available. With over 40,000 visits, 50,000 file downloads and over 250,000 page views to the end of 2019 , the value of the online resource is clear. ${ }^{56}$ It is to be hoped that a way is found to allow continued development; five years have now passed since data collection for RSRB ended and a very great deal more excavated data are now available to be assimilated and made available for further research and synthesis.

\section{ACKNOWLEDGEMENTS}

I am very grateful to Lisa Lodwick, Alex Smith and the anonymous Britannia referees for their very helpful comments on an earlier draft of this paper.

Department of Archaeology, University of Reading

m.g.fulford@reading.ac.uk

\section{BIBLIOGRAPHY}

Achard-Corompt, N., Audebert, A., Dessaint, M., Durost, R., and Le Quellec, V. 2017: 'Les modes d'occupation du sol ches les Rèmes', in Reddé 2017, 495-554

Allen, M. 2016: 'The South', in Smith et al. 2016, 75-140

Allen, M. 2017: 'Pastoral farming' in Allen et al. 2017, 85-141

56 New Visions of the Countryside of Roman Britain (Allen et al. 2017; Smith et al. 2016; 2018) is also being made available online: https://archaeologydataservice.ac.uk/library/browse/issue.xhtml?recordId=1161495\&recordType= MonographSeries (accessed February 2020). 
Allen, M., and Lodwick, L. 2017: 'Agricultural strategies in Roman Britain', in Allen et al. 2017, 142-77

Allen, M., Lodwick, L., Brindle, T., Fulford M., and Smith, A. 2017: The Rural Economy of Roman Britain, Britannia Monograph 30, London

Bernigaud, N., Berga, A., Blanchard, J., Blin, O., Boulen, M., Boulenger, L., Derreumaux, M., Lepetz, S., Toulemonde, F., and Zech-Matterne, V. 2017a: 'L'île de France', in Reddé 2017, 389-494

Bernigaud, N., Blondiau, L., Gaudefroy, S., Lepetz, S., Zech-Matterne, V., and Petit, C. 2017b: 'La région d'Amiens', in Reddé 2017, 249-301

Bowden, W. 2013: 'Townscape and identity at Caistor-by-Norwich', in H. Eckardt and S. Rippon (eds), Living and Working in the Roman World: Essays in Honour of Michael Fulford on his 65th Birthday, JRA Supplementary Series 95, Portsmouth, RI, 47-62

Branigan, K. 1976: 'Villa settlement in the West Country', in K. Branigan and P.J. Fowler (eds), The Roman West Country, Newton Abbot, 120-41

Brindle, T. 2016: 'The South-West', in Smith et al. 2016, 331-58

Brindle, T., and Lodwick, L. 2017: 'Textile production', in Allen et al. 2017, 221-30

Brüggler, M., Jeneson, K., Gerlach, R., Meurers-Balke, J., Zerl, T., and Herchenbach, M. 2017: 'The Roman Rhineland: farming and consumption in different landscapes', in Reddé 2017, 19-96

Clotuche, R., Derreumaux, M., Pigière, F., Jouanin, G., Preiss, S., and Yvinec, J.-H. 2017: 'Les campagnes du territoire Nervien: approaches croisées', in Reddé 2017, 179-210

Frere, S. 2000: 'A limitatio of Icenian territory?', Britannia 31, 350-5

Fulford, M. 2017: 'Conclusions', in Allen et al. 2017, 358-63

Fulford, M., and Brindle, T. 2016: 'Introduction', in Smith et al. 2016, 1-16

Fulford, M., and Holbrook, N. 2011: 'Assessing the contribution of commercial archaeology to the study of the Roman period in England, 1990-2004', Antiquaries Journal 91, 323-45

Fulford, M., and Holbrook, N. 2018: 'Relevant beyond the Roman period: approaches to the investigation, analysis and dissemination of archaeological investigations of the rural settlements and landscapes of Roman Britain', Archaeological Journal 175, 214-30

Kasprzyk, M. 2018: 'L'équipement et les formes des établissements ruraux du Bas-Empire (milieu du IIIemilieu du Ve siècle p. C.) dans l'est du diocèse des Gaules' in Reddé 2018, 235-305

Kasprzyk, M., and Monteil, M. 2017: Agglomérations, vici, et castra du Nord de la Gaule entre Antiquité tardive et début du haut Moyen Âge, Gallia 74.1, https://doi.org/10.4000/gallia.1319 (accessed March 2020)

Lepetz, S., and Zech-Matterne, V. 2018: 'Systèmes agro-pastoraux à l'âge du Fer et à la période romaine en Gaule du Nord', in Reddé 2018, 327-400

Lodwick, L. 2017: 'Arable farming: plant foods and resources', in Allen et al. 2017, 11-84

Malrain, F., and Lorho, T. 2018: 'L'organisation économique des campagnes du nord de la Gaule à La Tène finale', in Reddé 2018, 455-84

Malrain, F., Maréchal, D., de Muylder, M., Lepetz, S., Méniel, P., and Zech-Matterne, V. 2017: 'La vallée de l'Oise', in Reddé 2017, 303-52

Nüsslein, A. 2018: 'La géographie de la villa', in Reddé 2018, 181-226

Nüsslein, A., Bernigaud, N., with Reddé, M. 2018: 'Les établissements ruraux du haut empire', in Reddé 2018, 133-233

Petit, C., Bernigaud, N., Binois, A., Camizuli, E., Fajon, P., Fechner, K., Giosa, A., Parrondo, B., Rossignol, B., and Spiesser, J. 2018: 'Conditions environnementales de l'exploitation des espaces ruraux en Gaule du Nord', in Reddé 2018, 31-82

Reddé, M. (ed.) 2017: Gallia Rustica 1: les campagnes du nord-est de la Gaule, de la fin de l'âge du Fer à l'Antiquité tardive, Ausonius Éditions Mémoires 49, Bordeaux

Reddé, M. (ed.) 2018: Gallia Rustica 2: les campagnes du nord-est de la Gaule, de la fin de l'âge du Fer à l'Antiquité tardive, Ausonius Éditions Mémoires 50, Bordeaux

Reddé, M., Bernigaud, N., Lepetz, S., and Zech-Matterne, V. 2018: 'Les conditions du développement économique II: les marchés', in Reddé 2018, 519-84

Reynolds, P., and Langley, J. 1979: 'The Romano-British corn-drying oven: an experiment', Archaeological Journal 136, 27-42

Rivet, L. 1969: 'Social and economic aspects', in A.L.F. Rivet (ed.), The Roman Villa in Britain, London, 173216 
Rohnbogner, A. 2018: 'The rural population' in Smith et al. 2018, 281-345

Roymans, N. 2019: 'Conquest, mass violence and ethnic stereotyping: investigating Caesar's actions in the German frontier zone', Journal of Roman Archaeology 32, 439-58

Roymans, N., and Fernández-Götz, M. 2019: 'Reconsidering the Roman conquest: new archaeological perspectives', Journal of Roman Archaeology 32, 415-20

Sargent, A. 2002: 'The north-south divide revisited: thoughts on the character of Roman Britain', Britannia $33,219-26$

Shaffrey, R. 2015: 'Intensive milling practices in the Romano-British landscape of southern England: using newly established criteria for distinguishing millstones from rotary querns', Britannia 46, 55-92

Smith, A. 2016a: 'Buildings in the countryside', in Smith et al. 2016, 44-74

Smith, A. 2016b: 'The Central Belt', in Smith et al. 2016, 141-207

Smith, A. 2016c: 'The East' in Smith et al. 2016, 208-41

Smith, A. 2018: 'Death in the countryside: rural burial practice', in Smith et al. 2018, 205-80

Smith, A., and Fulford, M. 2018: 'Conclusions' in Smith et al. 2018, 346-57

Smith, A., and Fulford, M. 2019: 'The defended vici of Roman Britain: recent research and new agendas', Britannia 50, 109-47

Smith, A., Allen, M., Brindle, T., and Fulford, M. 2016: The Rural Settlement of Roman Britain, Britannia Monograph 29, London

Smith, A., Allen, M., Brindle, T., Fulford, M., Lodwick, L., and Rohnbogner, A. 2018: Life and Death in the Countryside of Roman Britain, Britannia Monograph 31, London

Spiesser, J., Petit, C., and Giosa, A. 2017: 'La basse vallée de la Seine' in Reddé 2017, 211-47

Taylor, J. 2007: An Atlas of Roman Rural Settlement in England, CBA Research Report 151, York 